OPINION

\title{
Traditional health practitioners and the authority to issue medical certificates
}

\begin{abstract}
B Tshehla
Boyane Tshehla is a lecturer in the Faculty of Law at North-West University (Mafikeng Campus), North West Province, South Africa. His research interests include the interaction between legal theory and practice. He focuses on the application, relevance and practicalities of the law in a social context.
\end{abstract}

Corresponding author: B Tshehla (boyane.tshehla@nwu.ac.za)

The Interim Traditional Health Practitioners Council was inaugurated in February 2013, and in May 2014 the sections of the Traditional Health Practitioners Act that give it full powers came into effect. The Council, as a professional body established by Parliament, gives traditional health practitioners registered with it the authority to issue medical certificates in line with the provisions of the Basic Conditions of Employment Act. However, the Council does not seem to be in a position to perform this function yet. Moreover, the field itself seems almost impossible to regulate because the practitioners cannot be subjected to objective assessment measures. While registered traditional health practitioners have the authority to issue medical certificates, it remains a moot point whether the certificates should be given full credibility before specific requirements for registration have been formulated and are implementable, and the envisaged code of conduct is in force.

S Afr Med J 2015;105(4):279-280. DOI:10.7196/SAMJ.9217

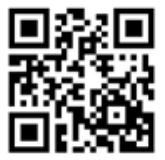

The Traditional Health Practitioners Act ${ }^{[1]}$ (the Act) was legislated in 2007 and has been progressively activated, with the result that the majority of its sections are in effect (sections $7,10,11(3), 12,13$, $14,15,47,48$ and 50 came into effect on 30 April 2008 (Proc. No. 17, GG 31020), and sections 4, 5, 6, 8, 9, 16, 17, 18-46, 49 and 51 on 1 May 2014 (Proc. No. 29 GG 37600). The sections promulgated so far include section 4 (see the speech by the Deputy Minister of Health on the day ${ }^{[2]}$ ), which establishes the Interim Traditional Health Practitioners Council (the Council). The Council, duly established and inaugurated at the beginning of 2013, has the status of a professional regulatory body. Chapter 2 of the Act $^{[1]}$ stipulates the functions of the Council, which has the powers to register practitioners who qualify, investigate complaints laid against them, remove such practitioners from the register, and perform many other related functions in the field of traditional health practice.

The Council was inaugurated in February 2013, and in May 2014 the sections of the Traditional Health Practitioners Act that give it full powers came into effect. The Council, as a professional body established by Parliament, gives traditional health practitioners registered with it the authority to issue medical certificates in line with the provisions of the Basic Conditions of Employment Act. ${ }^{[3]}$ However, the Council does not seem to be in a position to perform this function yet. Moreover, the field itself seems almost impossible to regulate because the practitioners cannot be subjected to objective assessment measures. While registered traditional health practitioners have the authority to issue medical certificates, it remains a moot point whether the certificates should be given full credibility before specific requirements for registration have been formulated and are implementable, and the envisaged code of conduct is in force.

This is an important development in the health sector of South Africa, given that the non-regulation of the traditional health sector created a lot of problems in the past. One of the obvious consequences of a non-regulated profession was that practitioners could not effectively be held accountable for their wrongful acts or omissions. One of the immediate effects of the establishment of the Council is the authority of traditional health practitioners to issue medical certificates for an employee who has been absent from work due to injury or sickness. This is a positive development, given that this particular issue has been a source of controversy for a considerable time. ${ }^{[4]}$ On the one hand, employees who preferred to consult traditional health practitioners found themselves in an untenable situation because some employers would not accept certificates issued by traditional health practitioners. On the other hand, employers found themselves in a situation where they had no mechanisms of establishing the authenticity of the certificate even if they were prepared to accept it, as there was no official body or council that could verify traditional health practitioners' credentials. The establishment of the Council fills this vacuum.

However, the Council does not seem capacitated to deliver satisfactorily on its mandate yet. There are a number of reasons for this, but prominent among them is the difficulty the Council is likely to face in selecting the credible practitioners from the bogus ones for registration purposes.

\section{Who is a traditional health practitioner?}

Section 1 of the $\operatorname{Act}^{[1]}$ defines a traditional health practitioner as a person who is 'registered under this Act in one or more of the categories of traditional health practitioners'. The categories of traditional health practitioners include 'diviners, herbalists, traditional birth attendants and traditional surgeons' (section 47(f)(i)). From the wording of the Act, it is evident that the Council has the responsibility of determining who is to be registered as a traditional health practitioner, and section 47 of the Act gives the Minister of Health the powers to issue regulations that deal with issues of qualification for registration. It is clear that the definition of a traditional health practitioner is wide enough to include almost anyone who has some ability to heal by traditional methods. Any person who engages in traditional health practice without first registering commits an offence. 
However, this provision is suspended for a period of a year after the promulgation of the Act. Given that the section that contains this provision came into effect on 1 May 2014, traditional health practitioners who are not registered have a grace period of a year from that date to practise.

\section{The traditional health practitioner's medical certificate and potential problems}

The absence of an employee from work is regulated by the provisions of the Basic Conditions of Employment Act. ${ }^{[3]}$ Section 23(1) of this Act states that ' $[a] n$ employer is not required to pay an employee in terms of section 22 if the employee has been absent from work for more than two consecutive days or on more than two occasions during an 8-week period and, on request by the employer, does not produce a medical certificate stating that the employee was unable to work for the duration of the employee's absence on account of sickness or injury'. Section 23(2) requires that 'the medical certificate must be issued and signed by a medical practitioner or any other person who is certified to diagnose and treat patients and who is registered with a professional council established by an Act of Parliament'.

By virtue of the Council being a professional body established in terms of an Act of Parliament, an employer will be obliged to accept a certificate from a registered traditional health practitioner. In theory that is sensible and equitable because, after all, people have a right to use health practitioners of their choice. The practical problem, however, is that this provision has come into effect before the measures according to which credible traditional health practitioners will be registered have been perfected. There are already reports that the process of registering traditional health practitioners seems subjective and biased in some instances. ${ }^{[5]}$ The problem is two-fold. Firstly, it is almost impossible to formulate an objective set of assessment measures to verify whether a person is a genuine traditional healer or not. Secondly, the Council has not yet perfected measures to conduct this assessment for registration purposes.

\section{Conclusion}

The establishment of a regulatory body dedicated to the traditional health practitioners' profession is long overdue and ought to be welcomed. It goes a long way in acknowledging that many South Africans rely on this profession for their medical needs and, in an employment situation, should not be disadvantaged because of their choice of medical practitioner.

Notwithstanding the appropriateness of the regulatory body, it seems that the establishment of the Council and its implications regarding the requirements of a valid medical certificate as contained in the Basic Conditions of Employment $\mathrm{Act}^{[3]}$ may create a lot of confusion and difficulties in the employment environment. An example of the problems a medical certificate and its validity can bring about came sharply to the fore in Kievits Kroon Country Estate (Pty) Ltd $v$ Mmoledi ${ }^{[4]}$ where an employer and employee were at odds regarding the validity of a certificate issued by a traditional healer. The case started at the Commission for Conciliation, Mediation and Arbitration, went to the Labour Court and then the Labour Appeal Court, and was eventually finalised in the Supreme Court of Appeal. While the Supreme Court of Appeal found in favour of the employee in this case, it did not make a finding on the validity or otherwise of a medical certificate issued by a traditional health practitioner.

Until the envisaged code of conduct is introduced and enforced, there is ample space for the abuse of this authority, and this will not only create difficulties in the employment environment but do serious damage to the credibility of traditional health practice.

\footnotetext{
1. Traditional Health Practitioners Act 22 of 2007. http://www.polity.org.za/article/traditional-healthractitioners-act-no-22-of-2007-2008-01-31 (accessed 24 February 2015).

Architect Africa News Network. Speech by Deputy Minister Gwen Ramokgopa at the inauguration of the Interim Traditional Health Practitioners Council of South Africa. http://architectafrica.
of com/NETWORK/SA/content/speech-deputy-minister-gwen-ramokgopa-inauguration-interimtraditional-health-practitioners- (accessed 1 December 2014).

traditional-health-practitioners- (accessed 1 December 2014).
3. Basic Conditions of Employment Act 75 of 1997. http://www.polity.org.za/article/basic3. Basic Conditions of Employment Act 75 of 1997. http://www.polity.org.za/article/basic-
conditions-of-employment-act-751997-determination-earrings-threshold-gazette-no-35404notice-422-2012-06-01 (accessed 24 February 2015)

4. Kievits Kroon Country Estate (Pty) Ltd v Mmoledi 2014 (1) SA 585 (SCA).

5. Summerton J. The incorporation of African traditional health practitioners into the South African health care system. Acta Academica 2006;38(1):143-169.
}

Accepted 13 February 2015. 